\title{
What Web Ads, Blurbs and Introductions Tell Potential Dictionary Buyers about Users, User Needs and Lexicographic Functions
}

\begin{abstract}
The present article deals with an investigation aimed at establishing the extent to which existing dictionaries provide potential dictionary buyers/borrowers with clear, unmistakable and easily understandable information about user need situations that might prompt consultation of the dictionary in question. The investigation analyses four monolingual English phrasal verbs dictionaries and five monolingual English specialised dictionaries. The primary sources of such information are identified as back cover blurbs of dictionaries, introductions to dictionaries and web ads for dictionaries. In the analysis, statements about user need situations extracted from these information sources are first classified as clear vs. unclear statements. The clear statements are then classified under the lexicographic function to which they are related. The results of the analysis disconfirm the hypothesis that the more well-defined and constrained the intended user group or groups for a given dictionary are, the more likely it is that the sources of information will provide the potential dictionary buyer/borrower with clear, unmistakable and easily understandable information about lexicographic function(s).
\end{abstract}

\section{Introduction}

For someone who finds himself/herself in a situation that requires the consultation of a dictionary to solve a particular problem, there are various sources of information which - in the ideal case can tell the potential dictionary user whether a given dictionary will satisfy his/her needs. If the need for consultation requires the purchase of a dictionary, the following sources of information are available. Students for example may ask teachers (and perhaps also fellow students) for advice. Other information sources include reviews, publishers' printed and online book catalogues, publishers' ads including publishers' web ads (usually linked to publishers' online catalogues), blurbs and book introductions (also called 'prefaces' or 'forewords').

This study will analyse publishers' ads (in this case web ads), back cover blurbs and book introductions for a number of monolingual English dictionaries with the purpose of establishing whether these sources of information provide the kind of information potential dictionary buyers or borrowers need. The analysis will be based on the functional theory of lexicography in the sense that it will attempt to uncover whether the three sources of information give clear, unmistakable and easily understandable information about the kind of user group or user groups the given dictionary is intended for and, more importantly, whether they provide the potential dictionary buyer with clear, unmistakable and easily understandable information about the lexicographic function(s) covered by the dictionary ${ }^{1}$, so that the potential dictionary buyer can readily establish whether the given dictionary will satisfy his/her extra-lexicographic needs.

The three sources of information mentioned have been selected for this study because they are readily available to the potential dictionary buyer (provided he/she has access through a computer

1 For the functional theory of lexicography in general and lexicographic functions in particular, see for example Tarp (2008)

* Birger Andersen

Department of Business Communication

School of Business and Social Sciences

Aarhus University

Jens Chr. Skous Vej 4

DK-8000 Aarhus $C$

ba@asb.dk 
to the Internet). Not all dictionaries are reviewed, and it may furthermore be difficult and timeconsuming for a potential dictionary buyer to locate a review of a particular dictionary. Also, publishers' printed book catalogues are rarely readily available.

With respect to 'introductions' (or 'prefaces/forewords'), they have only been included in the analysis if they are not too long or integrated into another front matter text. The longest introduction included in the study is the one found in Longman Phrasal Verbs Dictionary, stretching over three pages. The reason why long introductions or introductions integrated into other front matter texts should be excluded from the analysis is that potential dictionary buyers in the actual purchase situations are unlikely to read through very long texts in their search for relevant statements that can tell them whether the dictionary will satisfy their needs.

The dictionaries analysed fall into two groups:

a) Four monolingual English phrasal verbs dictionaries

b) Five monolingual English specialised dictionaries (all published by Oxford University Press $)^{2}$

The hypothesis is that the more well-defined and constrained the intended user group for a given dictionary is, the more likely it is that the sources of information will provide the potential dictionary buyer with clear, unmistakable and easily understandable information about lexicographic function(s). This is based on the assumption that it is much easier to define lexicographic function(s) for a clearly defined intended user group than for a diffuse user group.

The three types of information sources have previously been studied from a variety of perspectives, mainly by genre analysts who have studied them with the aim of establishing communicative purpose(s) for these genres. Bhatia (1997) is a study of academic book introductions in which he establishes that such introductions mix a descriptive communicative purpose with a promotional communicative purpose. It also includes a discussion of possible differences between the terms 'introduction', 'preface' and 'foreword', for example with respect to authorship of these texts. His conclusion is that it is largely impossible to set up any clear-cut distinctions with respect to communicative purpose, authorship, etc. between 'introductions', 'prefaces' and 'forewords'. For this reason, no distinction between them will be made in this study. Bhatia (2004: 168-181) analyses three book blurbs (two from academic works and one from fiction) and concludes that in fact all three blurbs share the same communicative purpose (description and evaluation), but there are differences between the fictional work on the one hand and the academic works on the other in terms of lexical choices in the blurbs, particularly with respect to adjectives. Gea-Valor (2005) investigates publishers' web site ads from four publishing companies (Penguin, Ballantine, Routledge, and Barnes \& Noble). She finds that these ads share communicative purposes (persuasive and informative) with blurbs to such an extent that they constitute a single genre. Kathpalia (1997) is a study of cross-cultural differences between book blurbs of international publishers and local Singapore-based publishers. Cacchiani (2007) is an investigation of evaluative language in book blurbs taken from what she calls 'lazy reads', whose communicative purpose is almost exclusively promotional, whereas Gesuato (2007) is a study of evaluative language in back-cover blurbs of academic books. Basturkmen (2009) is a study of the blurbs of seven English as a Foreign Language course books with a view to identifying the values of the English Language teaching community. This is done through a study of the key lexical items in the blurbs. Finally, Cronin/La Barre (2005) define blurbs as book recommendations on dust jackets written by named authors (called 'blurbers'), so that a book may contain more than one blurb. Their analysis of 450 non-fiction books (history and business) with a total of 1850 blurbs had the aim of discovering whether there exist 'serial blurbers' (authors writing inordinate numbers of blurbs) or 'back-scratching blurbers' (authors writing blurbs for each other's books on a regular basis), but this could not be confirmed by their study.

2 For references, see the bibliography. 
All of these studies are concerned with either works of fiction or academic prose works. None of them have studied web ads, blurbs or introductions for reference works such as dictionaries or encyclopedia. There is every reason to expect that web ads, blurbs and introductions for utility tools such as dictionaries and encyclopedia will differ in content and structure from web ads, blurbs and introductions for both fictional and academic prose works.

First of all, the genuine purpose of dictionaries and encyclopedia is to fulfil punctual (either communicative or cognitive) needs that arise in a range of extra-lexicographic situations, although some dictionaries contain outer matter texts with a genuine purpose that resembles that of academic prose works, i.e. to satisfy global cognitive needs. On the other hand, the genuine purpose of fictional works is to satisfy emotional, entertainment (and possibly other) needs, and the genuine purpose of academic works is to satisfy global cognitive (often educational) needs, although textbooks in particular are often provided with indexes to allow consultation to satisfy punctual cognitive needs.

Secondly, since dictionaries are compiled to cater for sometimes just one type of extra-lexicographic user need (monofunctional dictionaries), sometimes a multitude of extra-lexicographical user needs (polyfunctional dictionaries), potential dictionary buyers have a legitimate right to demand that those text genres that exist with the purpose of providing information about the user needs they were designed to fulfil give clear, unmistakable and easily understandable information about the data included in the dictionary to satisfy those user needs.

Gouws (2007) and Andersen/Fuertes-Olivera (2009) offer suggestions as to how this information can be formulated so as to give the potential dictionary buyer a clear indication of the communicative and/or cognitive needs a specific dictionary is meant to satisfy.

Gouws (2007) suggests that information about lexicographic function(s) could be given in the front matter texts of the dictionary. For a dictionary with both receptive and productive functions a formulation such as Help with the writing and understanding of texts would be very helpful. Likewise, for a dictionary with an exclusively cognitive function, the front matter texts could include a formulation such as Help with knowledge about language (or some other specific subject field).

Andersen/Fuertes-Olivera (2009) is an investigation, based on the functional theory of lexicography, of five English monolingual business dictionaries with the aim of suggesting a functionally based classification of such dictionaries. In addition, and more importantly in this context, they give some proposals for adding extra information (for example in the blurb) about the specific functions (and types of users) the dictionary is adequate for. They give the following proposals for the five business dictionaries investigated (adapted from Andersen/Fuertes-Olivera (2009: 236): 


\begin{tabular}{|l|l|}
\hline Dictionary & Captions in the blurb \\
\hline $\begin{array}{l}\text { Parkins, D. (ed.) 2005. Oxford Business English } \\
\text { Dictionary for Learners of English. Oxford: Oxford } \\
\text { University Press }\end{array}$ & $\begin{array}{l}\text { A communicatively oriented dictionary for semi- } \\
\text { experts and interested laymen with mostly text } \\
\text { production needs }\end{array}$ \\
$\begin{array}{l}\text { Summers, D. (ed.) 2007. Longman Business } \\
\text { English Dictionary, } 2^{\text {nd }} \text { ed. Harlow: Pearson } \\
\text { Longman }\end{array}$ & $\begin{array}{l}\text { A communicatively oriented dictionary, with a } \\
\text { laymen with both text production and text reception } \\
\text { needs }\end{array}$ \\
$\begin{array}{l}\text { Collin, P.H. 2001. Dictionary of Business, 3 } 3^{\text {rd }} \text { ed. } \\
\text { London: Peter Collin Publishing }\end{array}$ & $\begin{array}{l}\text { A balanced cognitively and communicatively } \\
\text { oriented dictionary for semi-experts and experts with } \\
\text { mostly text reception needs }\end{array}$ \\
$\begin{array}{l}\text { Law, J. (ed.) 2006. A Dictionary of Business and } \\
\text { Management, 4 ed. Oxford: Oxford University } \\
\text { Press }\end{array}$ & $\begin{array}{l}\text { A cognitively oriented dictionary for experts and } \\
\text { semi-experts with text reception needs }\end{array}$ \\
$\begin{array}{l}\text { Pass, C., B. Lowes, A. Pendleton, L. Chadwick, D. } \\
\text { O'Reilly \& M. Afferson 2005. Collins Dictionary } \\
\text { of Business, }{ }^{\text {rd }} \text { ed. Glasgow: Collins }\end{array}$ & $\begin{array}{l}\text { A cognitively oriented dictionary for experts and } \\
\text { semi-experts with text reception needs }\end{array}$ \\
\hline
\end{tabular}

Whether the theoretically oriented expressions such as A communicatively oriented dictionary, text production and text reception needs, etc. are adequate for a potential dictionary buyer with no knowledge of theoretical lexicographic terms can be questioned, but the proposals at least indicate in an unmistakable way which function(s) each dictionary is meant to satisfy.

\section{Methodology}

The methodology of this study consists in the extraction - from the three sources of information - statements that are judged to contain more or less clear descriptions or expressions of extralexicographic need situations that might prompt consultation of the dictionary in question and therefore a desire to buy (or borrow) it. The statements are simply divided into statements that are judged to be clear statements about user need situations and statements that are judged to be unclear statements about user need situations. All statements appear from Appendix A.

A statement such as

- it [i.e. the dictionary] explains their meaning [i.e. the meaning of the phrasal verbs] using uncomplicated language (Macmillan Phrasal Verbs Plus/Intro)

is judged to be a clear statement about the user need for assistance with respect to looking up the meaning of a phrasal verb whose meaning is unknown to the dictionary user. On the other hand, a statement such as

- up-to-date information about phrasal verbs in general English, as well as in business, Internet and computing contexts (Macmillan Phrasal Verbs Plus/Blurb)

is judged to be unclear, since it is not at all evident what sort of information is meant here. The term 'information' does not give any specific clues as to what specific user need or needs the data referred to by means of the term 'information' serve to satisfy. The statement

- all information needed to understand phrasal verbs (Macmillan Phrasal Verbs Plus/Intro)

however, has been classified as a clear statement, since the term 'information' here is clearly linked to the user need of finding out the meaning of a given phrasal verb.

In a few cases, statements have been classified as clear, although the sources of information have used terms that may be slightly confusing to potential dictionary buyers with respect to the satisfaction of user needs. Examples include 
- clear explanations (Macmillan Phrasal Verbs Plus/Web ad)

- new entries to explain the concepts, vocabulary and jargon associated with current theories of leadership, motivation, and team building (Oxford Dictionary of Business and Management/Preface)

where it is doubtful whether all potential dictionary buyers will interpret 'explanations/explain' as 'definitions/define' and thus conclude that the dictionary is intended to meet receptive needs. Another example is the statement

- explication of the new and sometimes baffling vocabulary associated with structured finance and the subprime lending crisis (Oxford Dictionary of Business and Management/Preface)

where it is even more doubtful that potential dictionary buyers will interpret the term 'explication' to mean that they will find definitions that will help them understand the meaning of the vocabulary items in question. The same applies to the statement

- clarification of everyday business terms (Oxford Dictionary of Business and Management/ Web ad)

However, since at least some dictionary users (perhaps the more experienced ones) may be able to unravel the probable intended meaning of these statements, they have been classified as clear statements.

In the lists of statements (see Appendix A), all extracted statements have been classified first as 'clear statements' or 'unclear statements'. Secondly, 'clear statements' have been classified under the lexicographic function to which they are related. A statement such as

- information about whether or not a phrasal verb is passive (Longman Phrasal Verbs Dictionary/Intro)

has been classified under the lexicographic function 'Production' since the statement is intended to provide the potential dictionary buyer with information about the capability of the phrasal verb to appear in the passive voice. ${ }^{3}$

A statement such as

- recommended web links for many entries - these links are a valuable source of extra information (Oxford Dictionary of Economics/Web ad)

has been classified under the lexicographic function 'Cognition', because it tells the potential dictionary buyer that the dictionary is capable of guiding him/her to other sources of information where additional knowledge about the entry word in question can be obtained.

A few statements in Macmillan Phrasal Verbs Plus, Cambridge Phrasal Verbs Dictionary and Oxford Phrasal Verbs have been classified under the lexicographic function 'Vocabulary Building'. This applies for example to the following statement:

- hundreds of synonyms and antonyms help build your vocabulary (Macmillan Phrasal Verbs Plus /Blurb)

In the traditional functional theory of lexicography, 'Vocabulary Building' will probably be viewed as a sub-function under 'Cognition'. However, since these learner's dictionaries explicitly refer to this (important) aspect of language learning, 'Vocabulary Building' has been set up in this study as a separate lexicographic function.

3 The statement might perhaps have been given a wording that more clearly indicates what the data about 'passive' can be used for, for example: 'information about whether or not a phrasal verb can be used in the passive'. 
The following two statements in Oxford Dictionary of Law have been related to two different functions, namely both 'Cognition' and 'Production':

- the Writing and Citation Guide provides detailed advice on how to write and present essays on legal subjects (Oxford Dictionary of Law/Preface)

- a useful Writing and Citation Guide that specifically addresses problems and establishes conventions for writing legal essays and reports (Oxford Dictionary of Law/Web ad)

In most cases, consultation of this Writing and Citation Guide will be for cognitive reasons, i.e. not related to any specific communicative-productive situation, but we cannot rule out the possibility that on rare occasions, the Guide may be consulted in a specific communicative-productive situation.

The same might perhaps apply to the following statements:

- Language Study articles on pronunciation, register, grammar, metaphor and learner errors (Macmillan Phrasal Verbs Plus/Blurb)

- explanations of how particles contribute to the meaning of phrasal verbs (Macmillan Phrasal Verbs Plus/Blurb)

However, in these cases it is very unlikely that users will consult these outer matter texts to solve communicative problems. They have therefore been classified only under the function 'Cognition'.

\section{Analysis}

\subsection{Users}

With respect to statements about intended users it clearly appears from the analysis that the four phrasal verbs dictionaries see themselves as English learner's dictionaries. This is explicitly stated in Macmillan Phrasal Verbs Plus/Intro, Cambridge Phrasal Verbs Dictionary/Intro, and in Oxford Phrasal Verbs/Blurb (front cover). Longman Phrasal Verbs Dictionary/Blurb further specifies that the dictionary is intended for 'advanced' and 'upper intermediate'learners of English.

Longman Phrasal Verbs Dictionary/Web ad, Cambridge Phrasal Verbs Dictionary/Intro and Oxford Phrasal Verbs/Web ad mention 'learners' as an intended user group without further specification of type of learner. The same implicit information is given through the use of the term 'students' in Longman Phrasal Verbs Dictionary/Blurb, Macmillan Phrasal Verbs Plus/Web ad, Cambridge Phrasal Verbs Dictionary/Web ad, and Oxford Phrasal Verbs/Web ad.

However, since all four dictionaries are monolingual English dictionaries, we must assume in all these cases that potential buyers of these dictionaries will take this information to mean that the dictionaries are intended for 'learners of English'.

Three of the phrasal verbs dictionaries restrict their intended user groups to this category whereas Longman Phrasal Verbs Dictionary/Blurb further gives 'general' as an intended user group. 'General' will probably have to be interpreted as 'the general public' and is probably included by the publishers in an attempt to reach as large a user market as possible.

However, on the whole it can be concluded that the four phrasal verbs dictionaries indicate that their intended user groups is quite clearly defined and constrained to learners of English.

With respect to intended user groups for the five specialised dictionaries, the picture is quite different. They all mention 'students' and 'professionals' (mainly of the relevant subject field, i.e. the subject field covered by the dictionary) as intended user groups, and with the exception of Oxford Dictionary of Accounting, they also see 'teachers/lecturers' (also mainly of the relevant subject field) as potential dictionary users. 'Teachers/lecturers' as potential users are mentioned mainly in the web ads. But then the picture becomes blurred, cf. the following statements: 
- all those interested in the financial world (Oxford Dictionary of Accounting/Preface)

- anyone who encounters accounting terms in their work (Oxford Dictionary of Accounting/ Web ad)

- anyone needing a guide to economic terms (Oxford Dictionary of Economics/Blurb)

- wide audience (Oxford Dictionary of Economics/Preface)

- anyone who has to deal with economic data or writing (Oxford Dictionary of Economics/ Web ad)

- anyone wanting a handy guide to legal terminology (Oxford Dictionary of Law/Blurb)

- laypeople who are affected by the law (Oxford Dictionary of Law/Preface)

- anyone needing clear definitions of legal terms (Oxford Dictionary of Law/Web ad)

- anyone involved in public finance or financial trading (Oxford Dictionary of Finance and Banking/Blurb)

- anyone needing clarification of commonly used business terms (Oxford Dictionary of Business and Management/Blurb)

- the general reader looking for clarification of everyday business terms (Oxford Dictionary of Business and Management/Web ad)

These statements alone clearly show that the compilers/publishers of these specialised dictionaries have had the intention of appealing to so far-reaching a user market that we are left with the impression that they have had no clear perception of whom the dictionaries are intended for. We must therefore conclude that the five specialised dictionaries have no clearly defined and constrained intended user group(s).

\subsection{Functions}

As mentioned in the Methodology section, statements about lexicographic functions of the dictionaries have been classified as clear, if there is no doubt about which user need(s) the statement refers to. That section provided a few examples. In the following, a few more examples are given, classified according to lexicographic function:

(a) 'Reception':

- clear simple definitions using the Longman 2000-word Defining Vocabulary (Longman Phrasal Verbs Dictionary/Blurb)

- over 100 cartoons illustrating meaning (Macmillan Phrasal Verbs Plus/Blurb)

- meanings are explained clearly and simply (Macmillan Phrasal Verbs Plus/Blurb)

- definitions of terms, concepts and jargon (Oxford Dictionary of Accounting/Blurb)

- 2,500 key economic terms, with clear, concise definitions (Oxford Dictionary of Economics/ Web ad)

(b) 'Production':

- clear grammar patterns show you how to use phrasal verbs (Longman Phrasal Verbs Diction- 
ary/Blurb)

- lists of collocations help you speak and write more naturally (Macmillan Phrasal Verbs Plus/ Blurb)

- clear advice on grammar and usage (Cambridge Phrasal Verbs Dictionary/Blurb)

- clear information about how formal or informal phrasal verbs are (Cambridge Phrasal Verbs Dictionary/Intro)

- 12,000 grammar codes show you the correct word order (Oxford Phrasal Verbs/Blurb)

(c) 'Cognition':

- a collection of articles [...] on topics such as syntax, register and pronunciation, to help students to develop a better awareness of how phrasal verbs work and why they are so useful (Macmillan Phrasal Verbs Plus/Intro)

- highlighted worked examples to help clarify difficult concepts (Oxford Dictionary of Accounting/Web ad)

- detailed appendices include Nobel Prize winners, the Greek alphabet, and commonly used acronyms (Oxford Dictionary of Economics/Blurb)

- highlighted feature entries discuss key topics in detail, for example adoption law, the appeals system $[\ldots]$ (Oxford Dictionary of Law/Web ad)

- recommended web links for many entries (Oxford Dictionary of Business and Management/ Blurb)

(d) 'Vocabulary Building':

- over 100 striking two-colour cartoons to illustrate common phrasal verbs [...] making them more memorable (Macmillan Phrasal Verbs Plus/Web ad, $2^{\text {nd }}$ level)

- a thematic section shows phrasal verbs in topic groups for vocabulary expansion (Cambridge Phrasal Verbs Dictionary/Web ad)

- synonyms and opposites help learners build their vocabulary (Oxford Phrasal Verbs/Web ad)

- hundreds of synonyms and antonyms help build your vocabulary (Macmillan Phrasal Verbs Plus/Blurb)

Not only do potential dictionary buyers have a legitimate claim to be told to what extent a given dictionary can satisfy (a range of) user needs. They also have a legitimate claim to be given this information in a language they can understand. We already touched upon this issue in the Introduction where it was questioned whether the formulations containing theoretical lexicographic terms suggested in Andersen/Fuertes-Olivera (2009) will be understood by potential dictionary buyers. Statements have therefore been classified as clear only if they avoid the use of such terms. In fact, no statement extracted from the nine dictionaries analysed have used theoretical lexicographical terms, and we can therefore conclude that all clear statements are also easily understandable statements.

An analysis of the main reasons for classifying statements as unclear with respect to the potential satisfaction of user needs reveals that for the phrasal verbs dictionaries many of these statements refer to linguistic data included in the dictionary articles or in outer matter texts, however 
without giving any clues as to which user needs they were included to satisfy. This applies for example to the following statement about synonyms and antonyms:

- if a phrasal verb has a synonym or a word that has almost the same meaning, this is shown at the end of that sense of the phrasal verb (Longman Phrasal Verbs Dictionary/Intro)

In two of the dictionaries, there are in fact clear statements about synonyms and antonyms, but there is not total agreement as to what this kind of linguistic data can be used for in terms of satisfying user needs. Macmillan Phrasal Verbs Plus states that synonyms and antonyms have been included to support 'Vocabulary Building':

- hundreds of synonyms and antonyms help build your vocabulary (Macmillan Phrasal Verbs Plus/Blurb)

- hundreds of synonyms and antonyms [...] help build students'vocabulary (Macmillan Phrasal Verbs Plus/Web ad $2^{\text {nd }}$ level)

Oxford Phrasal Verbs, however, states that the inclusion of synonyms and antonyms supports both 'Vocabulary Building' and 'Production':

- synonyms and opposites help learners build their vocabulary (Oxford Phrasal Verbs/Web ad)

- 2,000 synonyms and opposites help you choose the right word (Oxford Phrasal Verbs/Blurb)

Other unclear statements about linguistic data include the following:

- nouns and adjectives which are related to a phrasal verb are shown after the meaning of the phrasal verb they are derived from (Longman Phrasal Verbs Dictionary/Intro)

- an index of single-word verbs that have phrasal verb synonyms: using the index you can look up a word like inherit and find a phrasal verb - come into - with the same meaning (Macmillan Phrasal Verbs Plus/Intro)

- 'collocation boxes' providing invaluable information about the most frequent and naturalsounding combinations (Macmillan Phrasal Verbs Plus/Intro)

- thousands of example sentences based on the Cambridge International Corpus (Cambridge Phrasal Verbs Dictionary/Blurb)

- a list of single verbs that have a common phrasal verb equivalent (Cambridge Phrasal Verbs Dictionary/Intro)

- 'Guide to Particles' explains the most important meanings of the main adverbs and prepositions used in phrasal verbs to help learners see problems (Oxford Phrasal Verbs/Web ad)

Some statements refer to special layout features such as highlighting or the use of symbols, but again it is difficult to deduce from these statements which specific user needs the features were included to satisfy. Examples include:

- most common phrasal verbs are printed in blue boxes to show you that they are important to learn (Cambridge Phrasal Verbs Dictionary/Intro)

- most frequent verbs are highlighted in red (Macmillan Phrasal Verbs Plus/Blurb)

- most frequent phrasal verbs are highlighted [..] to show [...] how important they are for students to learn (Macmillan Phrasal Verbs Plus/Web ad $1^{\text {st }}$ level) 
- key symbol shows the 500 phrasal verbs you really need to know (Oxford Phrasal Verbs/ Blurb)

In the Methodology section we have already mentioned and given examples of nouns such as 'information' and 'coverage' whose meaning is too general to give clues as to the data referred to, unless the noun is modified in some way so as to give the potential buyer a clue to the user needs the data are intended to satisfy. Examples from the phrasal verbs dictionaries include the following:

- up-to-date information about phrasal verbs in general English, as well as in business, Internet and computing contexts (Macmillan Phrasal Verbs Plus/Blurb)

- we have identified just over 1,000 of the most frequently used English phrasal verbs [...] students and teachers have told us how useful this information is (Macmillan Phrasal Verbs Plus/Intro)

- coverage of phrasal verbs used in General English as well as in business, Internet and computing contexts (Macmillan Phrasal Verbs Plus)

However, this practice is especially widespread in the specialised dictionaries, particularly through the use of the noun 'coverage'. Examples include:

- coverage of terms commonly used in financial accounting (Oxford Dictionary of Accounting/ Preface)

- comprehensive coverage of financial accounting, management accounting [...] (Oxford Dictionary of Accounting /Web ad)

- strong international coverage of economic organizations and institutions (Oxford Dictionary of Economics/Blurb)

- expanded coverage of common econometric concepts (Oxford Dictionary of Economics/Web $\mathrm{ad})$

- expanded coverage of criminology and law enforcement (Oxford Dictionary of Law/Web ad)

- generous coverage of the terms used in government finance, the money supply (Oxford Dictionary of Finance and Banking/Preface)

- full coverage of the new and comprehensive Companies Act (Oxford Dictionary of Business and Management/Preface)

In a few statements, the verb 'cover' is used in the same way:

- covers all aspects of economics, including economic theory, applied microeconomics [...] (Oxford Dictionary of Economics/Web ad)

- covers important new legislation in company law, constitutional law [...] (Oxford Dictionary of Law/Web ad)

The verb 'include' is used in the same fashion in the following statement:

- includes marketing, accounting, organizational behaviour, global finance, business strategy, and taxation (Oxford Dictionary of Business and Management/Blurb)

In fact, the number of statements in the information sources for the specialised dictionaries with 'coverage/cover' without some form of modification to explain which user needs the 'coverage' 
intends to satisfy is 26 , i.e. almost half of the 56 unclear statements in the information sources for the specialised dictionaries.

A few statements for the specialised dictionaries refer to the dictionary as a whole using such terms as 'guide', '(source of) reference', 'reference work' or 'source of information'. Examples include:

- guide to assist professional advisers in their work (Oxford Dictionary of Accounting/Preface)

- an essential source of reference (Oxford Dictionary of Economics/Blurb)

- $\quad$ a handy guide to legal terminology (Oxford Dictionary of Law/Blurb)

- the authoritative A-Z guide to the world of money (Oxford Dictionary of Finance and Banking/Blurb (front cover))

These terms do not in any way in themselves give any assistance to the potential dictionary buyer with respect to revealing information about intended lexicographic functions.

Rough calculations of the proportion of clear statements to unclear statements about user needs in the three sources of information for the dictionaries analysed give the following results:

\begin{tabular}{|l|l|l|}
\hline Longman Phrasal Verbs Dictionary & Clear statements & Unclear statements \\
\hline Blurb & $100.0 \%$ & $0.0 \%$ \\
\hline Intro & $57.1 \%$ & $42.9 \%$ \\
\hline Web ad & $100.0 \%$ & $0.0 \%$ \\
\hline Total & $84.2 \%$ & $15.8 \%$ \\
\hline Macmillan Phrasal Verbs Plus & & \\
\hline Blurb & $63.6 \%$ & $36.4 \%$ \\
\hline Intro & $54.5 \%$ & $45.5 \%$ \\
\hline Web ad & $59.1 \%$ & $40.9 \%$ \\
\hline Total & $59.1 \%$ & $40.9 \%$ \\
\hline $\begin{array}{l}\text { Cambridge Phrasal Verbs } \\
\text { Dictionary }\end{array}$ & & \\
\hline Blurb & $28.6 \%$ & $71.4 \%$ \\
\hline Intro & $70.0 \%$ & $30.0 \%$ \\
\hline Web ad & $60.0 \%$ & $40.0 \%$ \\
\hline Total & $54.5 \%$ & $45.5 \%$ \\
\hline Oxford Phrasal Verbs & & \\
\hline Blurb & $69.2 \%$ & $30.8 \%$ \\
\hline Web ad & $80.0 \%$ & $20.0 \%$ \\
\hline Total & $73.9 \%$ & $26.1 \%$ \\
\hline Total Phrasal Verbs Dictionaries & $65.7 \%$ & $34.3 \%$ \\
\hline & &
\end{tabular}

Table 1. Proportion of clear statements to unclear statements in the three sources of information for the phrasal verbs dictionaries

4 See Appendix B for the absolute numbers of statements. 


\begin{tabular}{|c|c|c|}
\hline Oxford Dictionary of Accounting & Clear statements & Unclear statements \\
\hline Blurb & $75.0 \%$ & $25.0 \%$ \\
\hline Preface & $25.0 \%$ & $75.0 \%$ \\
\hline Web ad & $71.4 \%$ & $28.6 \%$ \\
\hline Total & $60.0 \%$ & $40.0 \%$ \\
\hline \multicolumn{3}{|l|}{ Oxford Dictionary of Economics } \\
\hline Blurb & $40.0 \%$ & $60.0 \%$ \\
\hline Preface & $50.0 \%$ & $50.0 \%$ \\
\hline Web ad & $36.4 \%$ & $63.4 \%$ \\
\hline Total & $40.9 \%$ & $59.1 \%$ \\
\hline \multicolumn{3}{|l|}{ Oxford Dictionary of Law } \\
\hline Blurb & $57.1 \%$ & $42.9 \%$ \\
\hline Preface & $71.4 \%$ & $28.6 \%$ \\
\hline Web ad & $50.0 \%$ & $50.0 \%$ \\
\hline Total & $58.3 \%$ & $41.7 \%$ \\
\hline \multicolumn{3}{|l|}{$\begin{array}{l}\text { Oxford Dictionary of Banking } \\
\text { and Finance }\end{array}$} \\
\hline Blurb & $33.3 \%$ & $66.7 \%$ \\
\hline Preface & $14.3 \%$ & $85.7 \%$ \\
\hline Web ad & $62.5 \%$ & $37.5 \%$ \\
\hline Total & $38.1 \%$ & $61.9 \%$ \\
\hline \multicolumn{3}{|l|}{$\begin{array}{l}\text { Oxford Dictionary of Business and } \\
\text { Management }\end{array}$} \\
\hline Blurb & $42.9 \%$ & $51.1 \%$ \\
\hline Preface & $33.3 \%$ & $66.7 \%$ \\
\hline Web ad & $33.3 \%$ & $66.7 \%$ \\
\hline Total & $36.4 \%$ & $63.6 \%$ \\
\hline Total specialised dictionaries & $46.2 \%$ & $53.8 \%$ \\
\hline
\end{tabular}

Table 2. Proportion of clear statements to unclear statements in the three sources of information for the specialised dictionaries

If we look first at the total proportion of clear statements to unclear statements in the sources of information for the two groups of dictionaries (phrasal verbs dictionaries vs specialised dictionaries) (Tables 1 and 2), it is evident that the phrasal verbs dictionaries do better than the specialised dictionaries with respect to providing the potential dictionary buyer with clear statements about the user needs the dictionaries are intended to satisfy.

First of all, however, the difference is not judged to be significant enough to fully support the hypothesis that the sources of information for dictionaries with clearly defined and clearly constrained intended user groups are much better at providing potential dictionary buyers with clear, unmistakable and easily understandable information about their capability of satisfying specific user needs.

Secondly, there are significant differences within each group of dictionaries in this respect. As far as the phrasal verbs dictionaries are concerned, Longman Phrasal Verbs Dictionary performs significantly better than Macmillan Phrasal Verbs Plus and Cambridge Phrasal Verbs Dictionary, and Oxford Phrasal Verbs performs somewhat better than Macmillan Phrasal Verbs Plus and Cambridge Phrasal Verbs Dictionary.

With respect to the specialised dictionaries, Oxford Dictionary of Accounting and Oxford Dictionary of Law stand out compared with the other three specialised dictionaries with respect to 
providing clear, unmistakable and easily understandable information about the user needs they were designed to satisfy. In fact, both of these dictionaries perform better than Cambridge Phrasal Verbs Dictionary and almost as well as Macmillan Phrasal Verbs Plus.

We must therefore conclude that the analysis cannot confirm the hypothesis that sources of information about lexicographic functions for dictionaries with clearly defined and constrained intended user groups are clearly better at providing potential dictionary buyers with clear, unmistakable and easily understandable information about the user needs they were designed to fulfil compared to sources of information for dictionaries with diffuse intended user groups.

\begin{tabular}{|l|l|l|}
\hline Phrasal Verbs Dictionaries & Clear statements & Unclear statements \\
\hline Blurbs & $66.7 \%$ & $33.3 \%$ \\
\hline Intros & $60.7 \%$ & $39.3 \%$ \\
\hline Web ads & $68.3 \%$ & $31.7 \%$ \\
\hline Specialised dictionaries & & \\
\hline Blurbs & $48.3 \%$ & $51.7 \%$ \\
\hline Prefaces & $40.0 \%$ & $60.0 \%$ \\
\hline Web ads & $48.9 \%$ & $51.1 \%$ \\
\hline Total for all dictionaries & & \\
\hline Blurbs & $58.8 \%$ & $41.2 \%$ \\
\hline Intros/Prefaces & $50.0 \%$ & $50.0 \%$ \\
\hline Web ads & $56.8 \%$ & $43.2 \%$ \\
\hline
\end{tabular}

Table 3. Total proportion of clear statements to unclear statements in the three sources of information

If we turn for a moment to each of the sources of information (Table 3) in order to see whether there are significant differences between them with respect to the proportion of clear statements to unclear statements, we can first of all conclude that the picture is quite similar for the two groups of dictionaries. The analysis shows that for both groups of dictionaries blurbs and web ads provide the potential dictionary buyer with a higher proportion of clear statements to unclear statements than the introductions/prefaces.

These results might be interesting if we could establish with certainty the authorship of each of the three types of information sources. We might assume that introductions/prefaces are mainly written by the editors/compilers of the dictionaries as a clear and objective guide to the contents and functions of the dictionaries. After all, editors/compilers may be expected to have a clear perception of who the intended users of their dictionaries are and which user needs they designed their dictionaries to satisfy - in other words the function or functions of their dictionaries. We might also assume that blurbs and web ads are mainly written by the publishers of the dictionaries as marketing tools for the dictionaries with a less clear perception of intended users and lexicographic function(s).

In essence, under these assumptions, we might expect introductions/prefaces to have a higher proportion of clear statements to unclear statements about lexicographic functions than the other two types of information sources.

Unfortunately, the literature does not provide us with a clear picture of the authorship of the three types of information sources. As already mentioned, Bhatia (1997) was unable to establish unequivocal authorship for introductions to academic books. With respect to the authorship of blurbs, Cronin/La Barre (2005: 19) says that "Blurbs are brief, effusive and often edited by the publisher", while Bhatia (2004: 170) says that "It is a bit difficult to decide who actually writes the blurb. Is it the author of the book or the publisher? Or may both of them have a role to play?". 
In any case, the remarks by both Cronin/La Barre and Bhatia relate to blurbs for academic books and should not be generalized so as to include also blurbs for reference works such as dictionaries. However, in four of the five specialised dictionaries ${ }^{5}$, the prefaces are initialled by the editor of the dictionary and in one of the four phrasal verbs dictionaries ${ }^{6}$, the introduction is signed by the chief editor of the dictionary, which must be taken as an indication that the introduction/preface was actually written by the editor. Table 4 shows the percentages of clear and unclear statements for these five dictionaries.

\begin{tabular}{|l|l|l|}
\hline & Clear statements & Unclear statements \\
\hline Specialised dictionaries & & \\
\hline Blurbs & $50.0 \%$ & $50.0 \%$ \\
\hline Prefaces & $37.5 \%$ & $62.5 \%$ \\
\hline Web ad & $52.9 \%$ & $47.1 \%$ \\
\hline Phrasal verbs dictionary & & \\
\hline Blurb & $63.6 \%$ & $36.4 \%$ \\
\hline Introduction & $54.5 \%$ & $45.5 \%$ \\
\hline Web ad & $59.1 \%$ & $40.9 \%$ \\
\hline
\end{tabular}

Table 4. Proportion of clear statements to unclear statements in the sources of information for four specialised dictionaries and one phrasal verbs dictionary

These results are remarkable if our assumptions with respect to authorship for blurbs and web ads hold, namely that these information sources are written by publishers' marketing people, particularly with respect to the specialised dictionaries, where the editors of the dictionaries are clearly more vague in their statements about dictionary functions. However, as already mentioned, verification of these conclusions will have to await further research into the authorship of the sources of information here investigated.

\section{Conclusion}

The hypothesis set forth in the introduction to this study - that the more well-defined and constrained the intended user groups for a given dictionary is, the more likely it is that the sources of information, on which potential dictionary buyers can rely prior to the purchase of the dictionary, will provide the potential dictionary buyer with clear, unmistakable and easily understandable information about lexicographic function(s), could not be confirmed.

First of all, the differences with respect to proportions of clear statements to unclear statements in the information sources for dictionaries with well-defined and constrained target user groups (the phrasal verbs dictionaries) and the proportions of clear statements to unclear statements in the information sources for dictionaries with rather ill-defined and unconstrained target user groups (the specialised dictionaries) were not judged to be significant enough to provide confirmation of the hypothesis.

Secondly, the analysis revealed significant differences within each group of dictionaries with respect to proportions of clear statements to unclear statements. These differences also serve to disconfirm the hypothesis.

5 Oxford Dictionary of Accounting, Oxford Dictionary of Business and Management, Oxford Dictionary of Finance and Banking and Oxford Dictionary of Law.

6 Macmillan Phrasal Verbs Plus 


\section{References}

\section{Dictionaries}

Cambridge Phrasal Verbs Dictionary = Walter, Elizabeth (ed.) 2006: CAMBRIDGE Phrasal Verbs Dictionary, $2^{\text {nd }}$ ed. Cambridge/New York/Melbourne/Madrid/Cape Town/Singapore/São Paulo: Cambridge University Press.

Longman Phrasal Verbs Dictionary = Summers, Della (ed.) 2000: LONGMAN Phrasal Verbs Dictionary. Harlow: Pearson Education Limited.

Macmillan Phrasal Verbs Plus = Rundell, Michael/Fox, Gwyneth (eds.) 2005: MACMILLAN Phrasal Verbs Plus. Oxford: Macmillan Education.

Oxford Dictionary of Accounting = Owen, Gary/Law, Jonathan (eds.) 2005: A Dictionary of Accounting, $3^{\text {rd }}$ ed. Oxford: Oxford University Press.

Oxford Dictionary of Business and Management = Law, Jonathan (ed.) 2009: A Dictionary of Business and Management, $5^{\text {th }} \mathrm{ed}$. Oxford: Oxford University Press.

Oxford Dictionary of Economics = Black, John/Hashimzade, Nigar/Myles, Gareth 2009: A Dictionary of Economics, $3^{r d}$ ed. Oxford: Oxford University Press.

Oxford Dictionary of Finance and Banking = Law, Jonathan (ed.) 2008: A Dictionary of Finance and Banking, $4^{\text {th }}$ ed. Oxford: Oxford University Press

Oxford Dictionary of Law $=$ Law, Jonathan/Martin, Elizabeth A. (eds.) 2009: A Dictionary of Law, $7^{\text {th }}$ ed. Oxford: Oxford University Press.

Oxford Phrasal Verbs = McIntosh, Colin (ed.) 2006: Oxford Phrasal Verbs Dictionary for Learners of English. Oxford: Oxford University Pres.

\section{Other literature}

Andersen, Birger/Fuertes-Olivera, Pedro A. 2009: The Application of Function Theory to the Classification of English Monolingual Business Dictionaries. In Lexicographica. International Annual for Lexicography 25, 213-239.

Bhatia, Vijay K. 1997: Genre-mixing in Academic Introductions. In English for Specific Purposes 16 (3), 181-195.

Bhatia, Vijay K. 2004: Worlds of Written Discourse. A Genre-Based View. London/New York: Continuum.

Basturkmen, Helen 2009: Back Cover Blurbs: Puff Pieces and Windows on Cultural Values. In Hyland K./Diani, G. (eds.), Review Genres in University Settings. Basingstoke: PalgraveMacMillan, 68-86.

Cacchiani, Silvia 2007: From Narratives to Intensification and Hyperbole: Promotional Uses of Book Blurbs. In Davies, M./Rayson, P./Hunston, S./Danielsson, P. (eds), Proceedings of the Corpus Linguistics Conference, University of Birmingham, 27-30 July, 2007 [online]. http://ucrel.lancs.ac.uk/publications/CL2007/paper/79_Paper.pdf (accessed 9 December 2011).

Cronin, Blaise/La Barre, Kathryn 2005: Patterns of puffery: an analysis of non-fiction blurbs. In Journal of Librarianship and Information Science 37 (1), 17-24.

Gea-Valor, Maria L. 2005: Advertising books: a linguistic analysis of blurbs. In Iberica 10, 41-62.

Gesuato, Sara 2007: Evaluation in Back-cover Blurbs. In Textus XX (1), 83-101.

Gouws, Rufus H. 2007: Op pad na 'n nuwe woordeboektipologie. In Southern African Linguistics and Applied Language Studies 25 (3), 319-331.

Kathpalia, Sujata, S. 1997: Cross-cultural variation in professional genres: a comparative study of book blurbs. In World Englishes 16 (3), 417-426.

Tarp, Sven 2008: Lexicography in the Borderland between Knowledge and Non-Knowledge. General Lexicographical Theory with Particular Focus on Learner's Lexicography. LEXICOGRAPHICA Series maior 134. Tübingen: Max Niemeyer Verlag. 


\section{Appendix A: Lists of statements}

In the following lists, passages in italics are comments by the author of this article.

\section{Phrasal verbs dictionaries}

\begin{tabular}{|c|c|c|}
\hline \multicolumn{3}{|c|}{ Longman Phrasal Verbs Dictionary } \\
\hline \multicolumn{3}{|c|}{ Functions } \\
\hline \multirow[t]{9}{*}{ BLURB } & \multicolumn{2}{|c|}{ CLEAR STATEMENTS } \\
\hline & Reception & all the information you need to understand phrasal verbs \\
\hline & Reception & clear simple definitions using the Longman 2000-word Defining Vocabulary \\
\hline & Reception & understanding phrasal verbs in newspapers, books \\
\hline & Reception & understanding phrasal verbs in spoken English \\
\hline & Production & (to understand phrasal verbs) and to use them correctly \\
\hline & Production & clear grammar patterns show you how to use phrasal verbs \\
\hline & Production & examples [...] show how phrasal verbs are really used in context \\
\hline & Production & unique Phrasal Verbs Activator ${ }^{\circledR}$ helps you choose the correct phrasal verb \\
\hline \multirow[t]{9}{*}{ INTRO } & \multicolumn{2}{|c|}{ CLEAR STATEMENTS } \\
\hline & Production & $\begin{array}{l}\text { demonstrates clearly how phrasal verbs are used with grammar patterns shown at each } \\
\text { sense }[\ldots] \text { whether a phrasal verb takes an object, where the object goes }[\ldots]\end{array}$ \\
\hline & Production & $\begin{array}{l}\text { the examples also show how this phrasal verb is used and how the position of the object } \\
\text { can vary }\end{array}$ \\
\hline & Production & information about whether or not a phrasal verb is passive $[\ldots]$ \\
\hline & Production & Examples also show this [that the verb does not take an object] \\
\hline & \multicolumn{2}{|c|}{ UNCLEAR STATEMENTS } \\
\hline & \multicolumn{2}{|c|}{ [list of] labels, (but no explicit mention of what they are good for) } \\
\hline & \multicolumn{2}{|c|}{$\begin{array}{l}\text { if a phrasal verb has a synonym or a word that has almost the same meaning, this is shown at the end of } \\
\text { that sense of the phrasal verb }\end{array}$} \\
\hline & \multicolumn{2}{|c|}{$\begin{array}{l}\text { nouns and adjectives which are related to a phrasal verb are shown after the meaning of the phrasal verb } \\
\text { they are derived from }\end{array}$} \\
\hline \multirow{5}{*}{$\begin{array}{l}\text { WEB } \\
\text { AD }\end{array}$} & \multicolumn{2}{|c|}{ CLEAR STATEMENTS } \\
\hline & Reception & helping you understand them [the phrasal verbs] \\
\hline & Production & helping you use them [the phrasal verbs] correctly \\
\hline & Production & $\begin{array}{l}\text { unique Phrasal Verbs Activator }{ }^{\circledR} \text { helps learners choose the right phrasal verb for the } \\
\text { context }\end{array}$ \\
\hline & Production & clear grammar patterns show how to use phrasal verbs \\
\hline \multicolumn{3}{|l|}{ Users } \\
\hline BLURB & \multicolumn{2}{|c|}{$\begin{array}{l}\text { a) teachers } \\
\text { b) students (advanced and upper intermediate) } \\
\text { c) general }\end{array}$} \\
\hline INTRO & \multicolumn{2}{|l|}{ N.A. } \\
\hline $\begin{array}{l}\text { WEB } \\
\text { AD }\end{array}$ & \multicolumn{2}{|c|}{ Learners (not further defined) } \\
\hline
\end{tabular}




\begin{tabular}{|c|c|c|}
\hline \multicolumn{3}{|c|}{ Macmillan Phrasal Verbs Plus } \\
\hline \multicolumn{3}{|c|}{ Functions } \\
\hline \multirow[t]{13}{*}{ BLURB } & \multicolumn{2}{|c|}{ CLEAR STATEMENTS } \\
\hline & Reception & easy-to-understand definitions use a 2000 -word vocabulary \\
\hline & Reception & over 100 cartoons illustrate meaning \\
\hline & Production & grammar patterns explained by real-life examples \\
\hline & Production & lists of collocations help you speak and write more naturally \\
\hline & Cognition & $\begin{array}{l}\text { Language Study articles on pronunciation, register, grammar, metaphor and learner } \\
\text { errors (unlikely to be consulted in communicative situations) }\end{array}$ \\
\hline & Cognition & $\begin{array}{l}\text { explanations of how particles contribute to the meaning of phrasal verbs (unlikely to be } \\
\text { consulted in communicative situations) }\end{array}$ \\
\hline & $\begin{array}{l}\text { Voc. } \\
\text { building }\end{array}$ & hundreds of synonyms and antonyms help build your vocabulary \\
\hline & \multicolumn{2}{|c|}{ UNCLEAR STATEMENTS } \\
\hline & \multicolumn{2}{|c|}{ two-colour dictionary with extra features to help you master phrasal verbs in English } \\
\hline & \multicolumn{2}{|c|}{ most frequent phrasal verbs are highlighted in red } \\
\hline & \multicolumn{2}{|c|}{ 'menus' guide you quickly to the meaning you want } \\
\hline & \multicolumn{2}{|c|}{$\begin{array}{l}\text { up-to-date information about phrasal verbs in general English, as well as in business, Internet and } \\
\text { computing contexts }\end{array}$} \\
\hline \multirow[t]{14}{*}{ INTRO } & \multicolumn{2}{|c|}{ CLEAR STATEMENTS } \\
\hline & Reception & all information needed to understand phrasal verbs \\
\hline & Reception & It [the dictionary] explains their meaning using uncomplicated language \\
\hline & Prodcution & all the information needed to use them [the phrasal verbs] well \\
\hline & Production & $\begin{array}{l}\text { gives an easy-to-understand description of their syntactic behaviour - how they } \\
\text { combine with other words, where the object can be placed, where pronouns go, and so } \\
\text { on }\end{array}$ \\
\hline & Production & $\begin{array}{l}\text { provides guidance on register - the types of context in which it is natural and } \\
\text { appropriate to use a phrasal verb }\end{array}$ \\
\hline & Cognition & $\begin{array}{l}\text { a collection of articles [...] on topics such as syntax, register, and pronunciation, to help } \\
\text { students to develop a better awareness of how phrasal verbs work and why they are so } \\
\text { useful (unlikely to be consulted in communicative situations) }\end{array}$ \\
\hline & \multicolumn{2}{|c|}{ UNCLEAR STATEMENTS } \\
\hline & \multicolumn{2}{|c|}{ help learners deal confidently with phrasal verbs } \\
\hline & \multicolumn{2}{|c|}{$\begin{array}{l}\text { we have identified just over } 1,000 \text { of the most frequently used English phrasal verbs }[\ldots] \text { students and } \\
\text { teachers have told us how useful this information is }\end{array}$} \\
\hline & \multicolumn{2}{|c|}{ menus - making it easy to find the meaning that you are looking for } \\
\hline & \multicolumn{2}{|c|}{$\begin{array}{l}\text { an index of single-word verbs that have phrasal verb synonyms: using the index, you can look up a } \\
\text { word like inherit and find a phrasal verb - come into - with the same meaning }\end{array}$} \\
\hline & \multicolumn{2}{|c|}{$\begin{array}{l}\text { 'collocation boxes', providing invaluable information about the most frequent and natural-sounding } \\
\text { combinations }\end{array}$} \\
\hline & \multicolumn{2}{|c|}{ special entries on the 12 most common particles } \\
\hline
\end{tabular}




\begin{tabular}{|c|c|c|}
\hline \multirow{10}{*}{$\begin{array}{l}\text { WEB AD } \\
1^{\text {ST }} \\
\text { LEVEL*) }^{*}\end{array}$} & \multicolumn{2}{|c|}{ CLEAR STATEMENTS } \\
\hline & Reception & clear explanations (= definitions?) \\
\hline & Production & a stimulus for natural-sounding English \\
\hline & Production & $\begin{array}{l}\text { an ideal reference to help learners }[\ldots] \text { start using them [the phrasal verbs] with } \\
\text { confidence }\end{array}$ \\
\hline & \multicolumn{2}{|c|}{ UNCLEAR STATEMENTS } \\
\hline & \multicolumn{2}{|c|}{ unique features to help students grasp this challenging and essential area of the English language } \\
\hline & \multicolumn{2}{|c|}{$\begin{array}{l}\text { most frequent phrasal verbs are highlighted }[\ldots] \text { to show }[\ldots] \text { how important they are for students to } \\
\text { learn }\end{array}$} \\
\hline & \multicolumn{2}{|c|}{ means for easy navigation } \\
\hline & \multicolumn{2}{|c|}{ an ideal reference to help learners lose their fear of phrasal verbs } \\
\hline & \multicolumn{2}{|c|}{ collocation boxes (with no further explanation) } \\
\hline \multirow{15}{*}{$\begin{array}{l}\text { WEB AD } \\
2^{\mathrm{ND}} \\
\text { LEVEL }\end{array}$} & \multicolumn{2}{|c|}{ CLEAR STATEMENTS } \\
\hline & Reception & definitions are written in a restricted vocabulary to make them easy to understand \\
\hline & Reception & $\begin{array}{l}\text { over } 100 \text { striking two-colour cartoons to illustrate common phrasal verbs reinforcing } \\
\text { their meaning }\end{array}$ \\
\hline & Production & $\begin{array}{l}\text { clear explanations of how to use every phrasal verb by means of grammar patterns and } \\
\text { relevant examples }\end{array}$ \\
\hline & Production & thousands of examples of phrasal verbs [...] reflect English as it is used today \\
\hline & Production & $\begin{array}{l}\text { Collocation boxes list the words phrasal verbs typically occur with, to help students } \\
\text { speak and write more clearly }\end{array}$ \\
\hline & Cognition & $\begin{array}{l}\text { explanations of how particular particles contribute to the meaning of phrasal verbs } \\
\text { (unlikely to be consulted in communicative situations) }\end{array}$ \\
\hline & Cognition & $\begin{array}{l}\text { information on inflections, pronunctiation, stress patterns, register and derivatives } \\
\text { widen students' knowledge of English }\end{array}$ \\
\hline & Cognition & $\begin{array}{l}\text { a 16-page Language Study section contains more detailed description of the } \\
\text { pronunciation, register and grammar of phrasal verbs (unlikely to be consulted in } \\
\text { communicative situations) }\end{array}$ \\
\hline & $\begin{array}{l}\text { Voc. } \\
\text { building }\end{array}$ & $\begin{array}{l}\text { over } 100 \text { striking two-colour cartoons to illustrate common phrasal verbs }[\ldots] \text { making } \\
\text { them more memorable }\end{array}$ \\
\hline & $\begin{array}{l}\text { Voc. } \\
\text { building }\end{array}$ & hundreds of synonyms and antonyms [...] help build students' vocabulary \\
\hline & \multicolumn{2}{|c|}{ UNCLEAR STATEMENTS } \\
\hline & \multicolumn{2}{|c|}{$\begin{array}{l}\text { coverage of phrasal verbs used in General English as well as in business, Internet and computing } \\
\text { contexts }\end{array}$} \\
\hline & \multicolumn{2}{|c|}{$\begin{array}{l}\text { the most frequent phrasal verbs are highlighted in red and graded with stars to show at a glance how } \\
\text { important they are for students to learn }\end{array}$} \\
\hline & \multicolumn{2}{|c|}{ menues in entries with five or more senses guide users quickly to the meaning they want } \\
\hline
\end{tabular}




\begin{tabular}{|l|l|}
\hline & $\begin{array}{l}\text { index of single-word equivalents enable learners to find phrasal verbs by starting with single-word } \\
\text { verbs which they already know }\end{array}$ \\
\hline Users \\
\hline BLURB & N.A. \\
\hline INTRO & learners of English \\
\hline WEB & $\begin{array}{l}1^{\text {st }} \text { level: students } \\
2^{\text {nd }} \text { level: students }\end{array}$ \\
\hline
\end{tabular}

*) The web ad is separated into two levels. The second level is accessible from the first level 


\begin{tabular}{|c|c|c|}
\hline \multicolumn{3}{|c|}{ Cambridge Phrasal Verbs dictionary } \\
\hline \multicolumn{3}{|c|}{ Functions } \\
\hline \multirow[t]{9}{*}{ BLURB } & \multicolumn{2}{|c|}{ CLEAR STATEMENTS } \\
\hline & Production & clear advice on grammar and usage \\
\hline & Cognition & topic pages covering useful language areas \\
\hline & \multicolumn{2}{|c|}{ UNCLEAR STATEMENTS } \\
\hline & \multicolumn{2}{|c|}{6,000 phrasal verbs explained in simple language } \\
\hline & \multicolumn{2}{|c|}{ shows you the most important phrasal verbs to learn } \\
\hline & \multicolumn{2}{|c|}{ lively new pictures illustrating many phrasal verbs } \\
\hline & \multicolumn{2}{|c|}{ photocopiable worksheets } \\
\hline & \multicolumn{2}{|c|}{ thousands of example sentences based on the Cambridge International Corpus } \\
\hline \multirow[t]{12}{*}{ INTRO } & \multicolumn{2}{|c|}{ CLEAR STATEMETNS } \\
\hline & Reception & helps larners of English to understand phrasal verbs \\
\hline & Reception & meanings are explained clearly and simply \\
\hline & Production & $\begin{array}{l}\text { helps learners of English [...] use them [the phrasal verbs] in a way that is natural and } \\
\text { appropriate }\end{array}$ \\
\hline & Production & examples show how they are used in context \\
\hline & Production & clear information about how formal or informal phrasal verbs are \\
\hline & Production & common grammar patterns and collocation \\
\hline & Production & topic pages which show ways of using phrasal verbs to talk about particular subjects \\
\hline & \multicolumn{2}{|c|}{ UNCLEAR STATEMENTS } \\
\hline & \multicolumn{2}{|c|}{ photocopiable worksheets to use either in class or for studying alone } \\
\hline & \multicolumn{2}{|c|}{ most common phrasal verbs are printed in blue boxes to show you that they are important to learn } \\
\hline & \multicolumn{2}{|c|}{ a list of single verbs that have a common phrasal verb equivalent } \\
\hline \multirow{7}{*}{$\begin{array}{l}\text { WEB } \\
\text { AD }\end{array}$} & \multicolumn{2}{|c|}{ CLEAR STATMENTS } \\
\hline & Production & clear advice on grammar and usage \\
\hline & Production & thousands of example sentences show phrasal verbs in typical contexts \\
\hline & Voc. building & a thematic section shows phrasal verbs in topic groups for vocabulary expansion \\
\hline & \multicolumn{2}{|c|}{ UNCLEAR STATEMENTS } \\
\hline & \multicolumn{2}{|c|}{$\begin{array}{l}\text { clear explanations and guidance help learners master this difficult yet essential aspect of the English } \\
\text { language }\end{array}$} \\
\hline & \multicolumn{2}{|c|}{ most common phrasal verbs highlighted so students know which to learn } \\
\hline \multicolumn{3}{|l|}{ Users } \\
\hline BLURB & \multicolumn{2}{|l|}{ N.A. } \\
\hline INTRO & \multicolumn{2}{|c|}{ learners of English } \\
\hline WEB & \multirow{2}{*}{\multicolumn{2}{|c|}{$\begin{array}{l}\text { a) learners } \\
\text { b) students }\end{array}$}} \\
\hline AD & & \\
\hline
\end{tabular}




\begin{tabular}{|c|c|c|}
\hline \multicolumn{3}{|c|}{ Oxford Phrasal Verbs } \\
\hline \multicolumn{3}{|c|}{ Functions } \\
\hline \multirow[t]{15}{*}{ BLURB } & \multicolumn{2}{|c|}{ CLEAR STATEMENTS } \\
\hline & Reception & understand phrasal verbs (and use them - confidently!) \\
\hline & Reception & 7,000 British and American phrasal verbs explained in words you understand \\
\hline & Production & (understand phrasal verbs) and use them - confidently! \\
\hline & Production & know when to use a phrasal verb or a one-word verb \\
\hline & Production & $\begin{array}{l}\text { 100+ synonym notes explain phrasal verbs and one-word verbs with similar meanings } \\
\text { so you make the right choice }\end{array}$ \\
\hline & Production & 12,000 examples help you use the verb correctly \\
\hline & Production & 4,000 collocations show you which words usually go together \\
\hline & Production & 2,000 synonyms and opposites help you choose the right word \\
\hline & Production & 12,000 grammar codes show you the correct word order \\
\hline & \multicolumn{2}{|c|}{ UNCLEAR STATEMENTS } \\
\hline & \multicolumn{2}{|c|}{ key symbol shows the 500 phrasal verbs you really need to know } \\
\hline & \multicolumn{2}{|c|}{ phrasal verbs in blue make it easy to find what you're looking for } \\
\hline & \multicolumn{2}{|c|}{ photocopiable study pages help you use the dictionary effectively - and practise phrasal verbs } \\
\hline & \multicolumn{2}{|c|}{ all the help you need to get plugged into phrasal verbs } \\
\hline INTRO & \multicolumn{2}{|c|}{ No introduction! } \\
\hline WEB & \multicolumn{2}{|c|}{ CLEAR STATEMENTS } \\
\hline & Reception & the information they need to understand over 6,000 British and American phrasal verbs \\
\hline & Reception & clear simple definitions \\
\hline & Production & the information they need to [...] use them [the phrasal verbs] correctly \\
\hline & Production & $\begin{array}{l}\text { give students help with synonyms, allowing them to decide whether a phrasal verb or a } \\
\text { single-word verb is the more appropriate choice }\end{array}$ \\
\hline & Production & with examples to show how phrasal verbs are used \\
\hline & Production & usage notes dealing with common problems help learners avoid typical mistakes \\
\hline & Production & common subject and objects are shown to help learners use the verbs appropriately \\
\hline & Voc. building & synonyms and opposites help learners build their vocabulary \\
\hline & \multicolumn{2}{|c|}{ UNCLEAR STATEMENTS } \\
\hline & \multicolumn{2}{|c|}{ tips and photocopiable exercises for classroom or indvidual practice } \\
\hline & \multicolumn{2}{|c|}{$\begin{array}{l}\text { 'Guide to Particles' explains the most important meanings of the main adverbs and prepositions used in } \\
\text { phrasal verbs to help learners see problems }\end{array}$} \\
\hline \multicolumn{3}{|l|}{ Users } \\
\hline BLURB & \multicolumn{2}{|c|}{ Front cover: learners of English } \\
\hline INTRO & \multicolumn{2}{|c|}{ No introduction! } \\
\hline $\begin{array}{l}\text { WEB } \\
\text { AD }\end{array}$ & \multicolumn{2}{|l|}{$\begin{array}{l}\text { a) students } \\
\text { b) learners }\end{array}$} \\
\hline
\end{tabular}




\section{Specialized dictionaries}

\begin{tabular}{|c|c|c|}
\hline \multicolumn{3}{|c|}{ Oxford Dictionary of Accounting } \\
\hline \multicolumn{3}{|l|}{ Functions } \\
\hline \multirow[t]{6}{*}{ BLURB } & \multicolumn{2}{|c|}{ CLEAR STATEMENTS } \\
\hline & Reception & definitions of terms, concepts and jargon \\
\hline & Cognition & web links \\
\hline & Cognition & feature entries on key topics \\
\hline & \multicolumn{2}{|c|}{ UNCLEAR STATEMENTS } \\
\hline & \multicolumn{2}{|c|}{ New features include worked examples } \\
\hline \multirow[t]{6}{*}{ PREFACE } & \multicolumn{2}{|c|}{ CLEAR STATEMENTS } \\
\hline & Reception & explanation of the jargon used in the financial world \\
\hline & \multicolumn{2}{|c|}{ UNCLEAR STATEMENTS } \\
\hline & \multicolumn{2}{|c|}{ source of reference for businessmen and businesswomen } \\
\hline & \multicolumn{2}{|c|}{ guide to assist professional advisers in their work } \\
\hline & \multicolumn{2}{|c|}{ coverage of terms commonly used in financial accounting } \\
\hline \multirow[t]{9}{*}{ WEB AD } & \multicolumn{2}{|c|}{ CLEAR STATEMENTS } \\
\hline & Reception & straightforward definitions of the latest financial jargon \\
\hline & Cognition & web links \\
\hline & Cognition & mini-chronologies of key events \\
\hline & Cognition & feature entries on key topics \\
\hline & Cognition & highlighted worked examples to help clarify difficult concepts \\
\hline & \multicolumn{2}{|c|}{ UNCLEAR STATEMENTS } \\
\hline & \multicolumn{2}{|c|}{ valuable guide to the often confusing world of accountancy terms } \\
\hline & \multicolumn{2}{|c|}{ comprehensive coverage of financial accounting, management accounting $[\ldots]$} \\
\hline \multicolumn{3}{|l|}{ Users } \\
\hline BLURB & \multicolumn{2}{|c|}{$\begin{array}{l}\text { a) students } \\
\text { b) professionals }\end{array}$} \\
\hline PREFACE & \multicolumn{2}{|c|}{$\begin{array}{l}\text { (From first edition): } \\
\text { a) all those interested in the financial world } \\
\text { b) students of all kinds, but especially students of accounting and business courses } \\
\text { c) businessmen and businesswomen } \\
\text { d) professional advisers }\end{array}$} \\
\hline WEB AD & \multicolumn{2}{|c|}{$\begin{array}{l}\text { a) students in the fields of accounting and finance } \\
\text { b) professionals in the fields of accounting and finance } \\
\text { READERSHIP (special section at the bottom of the web } a d \text { ): } \\
\text { a) students in the fields of accounting and finance } \\
\text { b) professionals in the fields of accounting and finance } \\
\text { c) anyone who encounters accounting terms in their work }\end{array}$} \\
\hline
\end{tabular}




\begin{tabular}{|c|c|c|}
\hline \multicolumn{3}{|c|}{ Oxford Dictionary of Economics } \\
\hline \multicolumn{3}{|l|}{ Functions } \\
\hline \multirow[t]{7}{*}{ BLURB } & \multicolumn{2}{|c|}{ CLEAR STATEMENTS } \\
\hline & Cognition & $\begin{array}{l}\text { detailed appendices include Nobel Prize winners, the Greek alphabet, and commonly } \\
\text { used acronyms }\end{array}$ \\
\hline & Cognition & recommended web links for many entries \\
\hline & \multicolumn{2}{|c|}{ UNCLEAR STATEMENTS } \\
\hline & \multicolumn{2}{|c|}{ guide to economic terms } \\
\hline & \multicolumn{2}{|c|}{ an essential source of reference } \\
\hline & \multicolumn{2}{|c|}{ strong international coverage of economic organizations and institutions } \\
\hline \multirow[t]{8}{*}{ PREFACE } & \multicolumn{2}{|c|}{ CLEAR STATEMENTS } \\
\hline & Reception & many useful definitions relating to personal finance, investments and financial markets \\
\hline & Reception & new entries on econometrics provide a technical definition \\
\hline & Cognition & $\begin{array}{l}\text { new entries on econometrics provide }[\ldots] \text { a brief explanation of the application of the } \\
\text { concept }\end{array}$ \\
\hline & \multicolumn{2}{|c|}{ UNCLEAR STATEMENTS } \\
\hline & \multicolumn{2}{|c|}{ a convenient source of reference } \\
\hline & \multicolumn{2}{|c|}{ descriptions of fundamental concepts } \\
\hline & \multicolumn{2}{|c|}{ entries on technical concepts } \\
\hline \multirow[t]{13}{*}{ WEB AD } & \multicolumn{2}{|c|}{ CLEAR STATEMENTS } \\
\hline & Reception & 2,500 key economic terms with clear, concise definitions \\
\hline & Cognition & $\begin{array}{l}\text { recommended web links for many entries - these links are a valuable source of extra } \\
\text { information }\end{array}$ \\
\hline & Cognition & $\begin{array}{l}\text { highlighted feature entries on major theoretical concepts such as agency, competition, } \\
\text { equilibrium, and efficiency }\end{array}$ \\
\hline & Cognition & appendices include Nobel Prize winners, the Greek alphabet and institutional acronyms \\
\hline & \multicolumn{2}{|c|}{ UNCLEAR STATEMENTS } \\
\hline & \multicolumn{2}{|c|}{ increased international coverage of economic organizations and institutions } \\
\hline & \multicolumn{2}{|c|}{ expanded coverage of common econometric concepts } \\
\hline & \multicolumn{2}{|c|}{ strong coverage of international trade } \\
\hline & \multicolumn{2}{|c|}{ covers all aspects of economics, including economic theory, applied microeconomics [...] } \\
\hline & \multicolumn{2}{|c|}{ many entries on economic organizations $[\ldots]$} \\
\hline & \multicolumn{2}{|c|}{ as ideal for browsing as it is useful for quick reference } \\
\hline & \multicolumn{2}{|c|}{ essential guide for students and teachers } \\
\hline \multicolumn{3}{|l|}{ Users } \\
\hline BLURB & \multicolumn{2}{|c|}{$\begin{array}{l}\text { a) students of economics, business and finance } \\
\text { b) professionals of economics, business and finance } \\
\text { c) anyone needing a guide to economic terms }\end{array}$} \\
\hline PREFACE & \multicolumn{2}{|c|}{$\begin{array}{l}\text { a) wide audience } \\
\text { b) students taking a first course in economics } \\
\text { c) non-specialist readers of journals such as The Economist } \\
\text { d) more advanced students }\end{array}$} \\
\hline
\end{tabular}




\begin{tabular}{|l|l|}
\hline WEB AD & e) professional economists \\
& $\begin{array}{l}\text { a) students of economics, business and finance } \\
\text { c) professional economists } \\
\text { d) anyone who has to deal with economic data } \\
\text { READERSHIP ( } \text { special section at the bottom of the web ad): } \\
\text { a) students of economics and the related fields of social studies, business studies and finance } \\
\text { b) teachers of economics and the related fields of social studies, business studies and finance } \\
\text { c) professional economists } \\
\text { d) those working in business and finance } \\
\text { e) anyone who has to deal with economic data or writing }\end{array}$ \\
\hline
\end{tabular}




\begin{tabular}{|c|c|c|}
\hline \multicolumn{3}{|c|}{ Oxford Dictionary of Law } \\
\hline \multicolumn{3}{|l|}{ Functions } \\
\hline \multirow[t]{9}{*}{ BLURB } & \multicolumn{2}{|c|}{ CLEAR STATEMENTS } \\
\hline & Reception & explaining the major terms, concepts \\
\hline & Production & a Writing and Citation Guide to help with legal essays and reports \\
\hline & Cognition & explaining the major $[\ldots]$ processes and the organization of the English legal system \\
\hline & Cognition & recommended web links for many entries \\
\hline & \multicolumn{2}{|c|}{ UNCLEAR STATEMENTS } \\
\hline & \multicolumn{2}{|c|}{ a handy guide to legal terminology } \\
\hline & \multicolumn{2}{|c|}{ an authoritative source of jargon-free legal information } \\
\hline & \multicolumn{2}{|c|}{ companion website (no specification of contents) } \\
\hline \multirow[t]{9}{*}{ PREFACE } & \multicolumn{2}{|c|}{ CLEAR STATEMENTS } \\
\hline & Reception & a clear defintion of the entry word (or words) \\
\hline & Cognition & $\begin{array}{l}\text { (a clear definition of the entry word }[\ldots . .] \text { ) which in most cases is followed by a more } \\
\text { detailed explanation or description of the concepts involved }\end{array}$ \\
\hline & Cognition & an introduction to the legal resources now available on the internet \\
\hline & Cognition & references to important new cases with full citations have $[\ldots]$ been added $[\ldots]$ \\
\hline & $\begin{array}{l}\text { Cognition/ } \\
\text { Production }\end{array}$ & $\begin{array}{l}\text { the Writing and Citation Guide provides detailed advice on how to write and present } \\
\text { essays on legal subjects }\end{array}$ \\
\hline & \multicolumn{2}{|c|}{ UNCLEAR STATEMENTS } \\
\hline & \multicolumn{2}{|c|}{ emphasis on accessible language } \\
\hline & \multicolumn{2}{|c|}{$\begin{array}{l}\text { some entries simply refer the reader to another entry, indicating either that they are synonyms or } \\
\text { abbreviations or that they are most conveniently explained in one of the dictionary's longer articles }\end{array}$} \\
\hline \multirow[t]{12}{*}{ WEB AD } & \multicolumn{2}{|c|}{ CLEAR STATEMENTS } \\
\hline & Reception & defines all the major terms, concepts \\
\hline & $\begin{array}{l}\text { Cognition/ } \\
\text { Production }\end{array}$ & $\begin{array}{l}\text { a useful Writing and Citation Guide that specifically addresses problems and established } \\
\text { conventions for writing legal essays and reports }\end{array}$ \\
\hline & Cognition & defines all the major [...] processes and the organization of the English legal system \\
\hline & Cognition & $\begin{array}{l}\text { highlighted feature entries discuss key topics in detail, for example adoption law, the } \\
\text { appeals system [...] }\end{array}$ \\
\hline & Cognition & recommended web links for many entries \\
\hline & \multicolumn{2}{|c|}{ UNCLEAR STATEMENTS } \\
\hline & \multicolumn{2}{|c|}{ covers important new legislation in company law, constitutional law, criminal law, and many other areas } \\
\hline & \multicolumn{2}{|c|}{ includes terms taken from European, international, human rights, and environmental law } \\
\hline & \multicolumn{2}{|c|}{ invaluable source of legal reference } \\
\hline & \multicolumn{2}{|c|}{ one-stop source of information } \\
\hline & \multicolumn{2}{|c|}{ expanded coverage of criminology and law enforcement } \\
\hline \multicolumn{3}{|l|}{ Users } \\
\hline BLURB & \multicolumn{2}{|c|}{$\begin{array}{l}\text { a) students } \\
\text { b) professionals } \\
\text { c) anyone wanting a handy guide to legal terminology } \\
\text { Quote from Times Educational Supplement: }\end{array}$} \\
\hline
\end{tabular}




\begin{tabular}{|c|c|}
\hline & Precision for the professional is combined with a layman's enlightenment \\
\hline PREFACE & $\begin{array}{l}\text { a) legal professionals who sometimes need a quick, portable and reliable reference source } \\
\text { b) students following law courses at all levels, who require clear explanations of legal concepts and } \\
\text { terminology } \\
\text { c) professionals in other fields (e.g. business people, local government officials, accountants and social } \\
\text { workers) who require some knowledge of the law in their work } \\
\text { d) laypeople who are affected by the law }\end{array}$ \\
\hline WEB AD & $\begin{array}{l}\text { a) professionals } \\
\text { b) students } \\
\text { c) anyone else, needing succinct clarification of legal terms } \\
\text { Quote from 'leading university lecturers: } \\
\text { a) non-law students } \\
\text { b) law undergraduates } \\
\text { READERSHIP (special section at the bottom of the web ad): } \\
\text { a) students of law } \\
\text { b) lecturers of law } \\
\text { c) professional lawyers } \\
\text { d) anyone needing clear definitions of legal terms }\end{array}$ \\
\hline
\end{tabular}




\begin{tabular}{|c|c|c|}
\hline \multicolumn{3}{|c|}{ Oxford Dictionary of Finance and Banking } \\
\hline \multicolumn{3}{|l|}{ Functions } \\
\hline \multirow[t]{8}{*}{ BLURB } & \multicolumn{2}{|c|}{ CLEAR STATEMENTS } \\
\hline & Cognition & $\begin{array}{l}\text { new feature panels on key topics including the Financial Times Share indexes and } \\
\text { banktruptcy law }\end{array}$ \\
\hline & Cognition & recommended web links for many entries \\
\hline & \multicolumn{2}{|c|}{ UNCLEAR STATEMENTS } \\
\hline & \multicolumn{2}{|c|}{ expanded coverage of central banking and monetary policy } \\
\hline & \multicolumn{2}{|c|}{ up-to-date coverage of the world's important financial centres } \\
\hline & \multicolumn{2}{|c|}{ the authoritative A-Z guide to the world of money (front cover) } \\
\hline & \multicolumn{2}{|c|}{$\begin{array}{l}\text { this best-selling dictionary covers all apsects of finance and banking, from personal investments to } \\
\text { international trading }\end{array}$} \\
\hline \multirow[t]{9}{*}{ PREFACE } & \multicolumn{2}{|c|}{ CLEAR STATEMENTS } \\
\hline & Cognition & feature pages $[\ldots]$ on a number of key topics \\
\hline & \multicolumn{2}{|c|}{ UNCLEAR STATEMENTS } \\
\hline & \multicolumn{2}{|c|}{ up-to-date coverage of the vocabulary used in banking, money markets [...] } \\
\hline & \multicolumn{2}{|c|}{ generous coverage of the terms used in government finance, the money supply $[\ldots]$} \\
\hline & \multicolumn{2}{|c|}{ entries for terms related to savings, stock-exchange dealing $[\ldots]$} \\
\hline & \multicolumn{2}{|c|}{ coverage of central banking and monetary policy has been substantially expanded [...] } \\
\hline & \multicolumn{2}{|c|}{ the coverage is truly international with entries for all the world's standard currency units $[\ldots]$} \\
\hline & \multicolumn{2}{|c|}{ synonyms and abbreviations are ususally found within brackets immediately following a headword } \\
\hline \multirow[t]{10}{*}{ WEB AD } & \multicolumn{2}{|c|}{ CLEAR STATEMENTS } \\
\hline & Reception & defines terms from all aspects of personal and international finance \\
\hline & Reception & clear and accessible definitions \\
\hline & Cognition & recommended web links for many entries \\
\hline & Cognition & useful feature entries on areas requiring a fuller explanation \\
\hline & Cognition & feature panels with full explanations of topical and complex terms \\
\hline & \multicolumn{2}{|c|}{ UNCLEAR STATEMENTS } \\
\hline & \multicolumn{2}{|c|}{ covers all aspects of personal and international finance $[\ldots]$} \\
\hline & \multicolumn{2}{|c|}{ expanded coverage of central banking $[\ldots]$} \\
\hline & \multicolumn{2}{|c|}{ provides accurate and valuable information for students [...] } \\
\hline \multicolumn{3}{|l|}{ Users } \\
\hline BLURB & \multicolumn{2}{|c|}{$\begin{array}{l}\text { a) students of accounting, banking and commerce } \\
\text { b) professionals of accountancy, banking and commerce } \\
\text { c) anyone involved in public finance or financial trading }\end{array}$} \\
\hline PREFACE & \multicolumn{2}{|c|}{$\begin{array}{l}\text { a) students in the fields of finance and banking } \\
\text { b) professionals in the fields of finance and banking } \\
\text { c) private investors } \\
\text { d) readers of the financial pages of newspapers } \\
\text { e) the private investor and borrower }\end{array}$} \\
\hline WEB AD & \multicolumn{2}{|c|}{$\begin{array}{l}\text { a) students, practitioners, private investors and readers of the financial pages alike } \\
\text { READERSHIP (special section at the bottom of the web ad): }\end{array}$} \\
\hline
\end{tabular}




\begin{tabular}{|l|l|}
\hline a) professionals working in accountancy, banking, commerce, public finance, and related fields \\
b) private investors \\
c) readers of the financial pages \\
d) small businesses \\
e) students of finance, banking, economics, and business \\
f) lecturers of finance, banking, economics, and business
\end{tabular}




\begin{tabular}{|c|c|c|}
\hline \multicolumn{3}{|c|}{ Oxford Dictionary of Business and Management } \\
\hline \multicolumn{3}{|l|}{ Functions } \\
\hline \multirow[t]{9}{*}{ BLURB } & \multicolumn{2}{|c|}{ CLEAR STATEMENTS } \\
\hline & Reception & clearly defines the very latest terminology used in business and management \\
\hline & Reception & clear, concise, and up-to-date definitions for 7,000 terms (front cover) \\
\hline & Cognition & recommended web links for many entries \\
\hline & \multicolumn{2}{|c|}{ UNCLEAR STATEMENTS } \\
\hline & \multicolumn{2}{|c|}{ an essential A-Z for students [...] } \\
\hline & \multicolumn{2}{|c|}{ expanded coverage of modern financial jargon, strategic management, and human resources } \\
\hline & \multicolumn{2}{|c|}{ includes marketing, accounting, organizational behaviour, global finance, business strategy, and taxation } \\
\hline & \multicolumn{2}{|c|}{ US business terms, general management concepts, and named theories } \\
\hline \multirow[t]{4}{*}{$\begin{array}{l}\text { PREFACE } \\
\left(4^{\text {TH }} \text { ED. }\right)\end{array}$} & \multicolumn{2}{|c|}{ CLEAR STATEMENTS } \\
\hline & Reception & $\begin{array}{l}\text { new entries to explain (= define?) the concepts, vocabulary and jargon associated with } \\
\text { current theories of leadership, motivation, and team building }\end{array}$ \\
\hline & \multicolumn{2}{|c|}{ UNCLEAR STATEMENTS } \\
\hline & \multicolumn{2}{|c|}{ greatly increased coverage of management terms and theory } \\
\hline \multirow[t]{6}{*}{$\begin{array}{l}\text { PREFACE } \\
\left(5^{\text {TH }} \text { ED. }\right)\end{array}$} & \multicolumn{2}{|c|}{ CLEAR STATEMENTS } \\
\hline & Reception & $\begin{array}{l}\text { Explication (= definition?) of the new and sometimes baffling vocabulary associated } \\
\text { with structured finance and the subprime lending crisis }\end{array}$ \\
\hline & \multicolumn{2}{|c|}{ UNCLEAR STATEMENTS } \\
\hline & \multicolumn{2}{|c|}{$\begin{array}{l}\text { enhanced coverage of such areas as behavioural finance, strategic management, and the contemporary } \\
\text { theory of the firm }\end{array}$} \\
\hline & \multicolumn{2}{|c|}{ full coverage of the new and comprehensive Companies Act } \\
\hline & \multicolumn{2}{|c|}{ synonyms and abbreviations are usually found within brackets immediately following a headword } \\
\hline \multirow[t]{11}{*}{ WEB AD } & \multicolumn{2}{|c|}{ CLEAR STATEMENTS } \\
\hline & Reception & $\begin{array}{l}\text { dispels modern financial and management jargon, defining entries in a clear, concise and } \\
\text { accessible manner }\end{array}$ \\
\hline & Reception & Clarification (= definition?) of everyday business terms \\
\hline & Cognition & recommended web links for many entries \\
\hline & \multicolumn{2}{|c|}{ UNCLEAR STATEMENTS } \\
\hline & \multicolumn{2}{|c|}{ guide to business terminology } \\
\hline & \multicolumn{2}{|c|}{ up-to-date coverage of fast-changing fields, including the new Companies Act [...] } \\
\hline & \multicolumn{2}{|c|}{ full coverage of the important new Companies Act } \\
\hline & \multicolumn{2}{|c|}{ expanded coverage of modern financial jargon, strategic management and human resources } \\
\hline & \multicolumn{2}{|c|}{ expanded coverage of the contemporary theory of the firm and human resources } \\
\hline & \multicolumn{2}{|c|}{ reference work } \\
\hline \multicolumn{3}{|l|}{ Users } \\
\hline BLURB & \multicolumn{2}{|c|}{$\begin{array}{l}\text { a) students } \\
\text { b) teachers } \\
\text { c) professionals }\end{array}$} \\
\hline
\end{tabular}




\begin{tabular}{|l|l|}
\hline $\begin{array}{l}\text { PREFACE } \\
\left(\mathbf{1}^{\text {ST }} \text { ED. }\right)\end{array}$ & $\begin{array}{l}\text { d) anyone needing clarification of commonly used business terms } \\
\text { b) teachers } \\
\text { c) professional advisers (lawyers, bankers, accountants, managers, insurers, etc.) }\end{array}$ \\
\hline WEB AD & $\begin{array}{l}\text { a) business students } \\
\text { b) teachers } \\
\text { c) professionals } \\
\text { d) anyone needing a guide to business terminology } \\
\text { READERSHIP (special section at the bottom of the web ad): } \\
\text { a) students on business and management courses at all levels } \\
\text { b) business professionals including lawyers, bankers, accountants, advertising agents and insurance } \\
\text { brokers } \\
\text { c) the general reader looking for clarification of everyday business terms (encountered, for example, in } \\
\text { house-buying, tax returns, or share investment) }\end{array}$ \\
\hline
\end{tabular}


Appendix B: Number of statements

\begin{tabular}{|c|c|c|c|c|c|c|c|c|c|c|}
\hline & $\begin{array}{l}\text { Clear } \\
\text { state- } \\
\text { ments }\end{array}$ & Total & $\begin{array}{l}\text { Phrasal } \\
\text { verbs } \\
\text { total }\end{array}$ & Total & $\begin{array}{l}\text { Spec. } \\
\text { dict. } \\
\text { Total }\end{array}$ & $\begin{array}{l}\text { Unclear } \\
\text { state- } \\
\text { ments }\end{array}$ & Total & $\begin{array}{l}\text { Phrasal } \\
\text { verbs } \\
\text { total }\end{array}$ & Total & $\begin{array}{l}\text { Spec. } \\
\text { dict. } \\
\text { Total }\end{array}$ \\
\hline \multicolumn{11}{|l|}{$\begin{array}{l}\text { Phrasal } \\
\text { verbs }\end{array}$} \\
\hline \multicolumn{11}{|c|}{ Longman } \\
\hline Blurb & 8 & & & & & 0 & & & & \\
\hline Intro & 4 & & & & & 3 & & & & \\
\hline Web ad & 4 & 16 & & & & 0 & 3 & & & \\
\hline \multicolumn{11}{|c|}{ Macmillan } \\
\hline Blurb & 7 & & & & & 4 & & & & \\
\hline Intro & 6 & & & & & 5 & & & & \\
\hline Web ad & 13 & 26 & & & & 9 & 18 & & & \\
\hline \multicolumn{11}{|c|}{ Cambridge } \\
\hline Blurb & 2 & & & & & 5 & & & & \\
\hline Intro & 7 & & & & & 3 & & & & \\
\hline Web ad & 3 & 12 & & & & 2 & 10 & & & \\
\hline \multicolumn{11}{|l|}{ Oxford } \\
\hline Blurb & 9 & & & & & 4 & & & & \\
\hline Web ad & 8 & 17 & 71 & & & 2 & 6 & 37 & & \\
\hline \multicolumn{11}{|c|}{$\begin{array}{l}\text { Specialised } \\
\text { dictionaries }\end{array}$} \\
\hline \multicolumn{11}{|l|}{ Oxf. Acc } \\
\hline Blurb & 3 & & & & & 1 & & & & \\
\hline Preface & 1 & & & & & 3 & & & & \\
\hline Web ad & 5 & & & 9 & & 2 & & & 6 & \\
\hline \multicolumn{11}{|c|}{ Oxf. Econ } \\
\hline Blurb & 2 & & & & & 3 & & & & \\
\hline Preface & 3 & & & & & 3 & & & & \\
\hline Web ad & 4 & & & 9 & & 7 & & & 13 & \\
\hline \multicolumn{11}{|c|}{ Oxf. Law } \\
\hline Blurb & 4 & & & & & 3 & & & & \\
\hline Preface & 5 & & & & & 2 & & & & \\
\hline Web ad & 5 & & & 14 & & 5 & & & 10 & \\
\hline \multicolumn{11}{|c|}{ Oxf. B\&F } \\
\hline Blurb & 2 & & & & & 4 & & & & \\
\hline Preface & 1 & & & & & 6 & & & & \\
\hline Web ad & 5 & & & 8 & & 3 & & & 13 & \\
\hline \multicolumn{11}{|c|}{ Oxf. B\&M } \\
\hline Blurb & 3 & & & & & 4 & & & & \\
\hline Preface & 2 & & & & & 4 & & & & \\
\hline Web ad & 3 & & & 8 & 48 & 6 & & & 14 & 56 \\
\hline
\end{tabular}


